\title{
Paranormal Aspects of Pre-Existence Memories in Young Children
}

\author{
Titus Rivas, MA, MSc \\ Nijmegen, The Netherlands \\ Elizabeth M. Carman, LHD, and Neil J. Carman, PhD \\ Austin, TX \\ Anny Dirven \\ Budel, The Netherlands
}

\begin{abstract}
The authors present both unconfirmed and externally confirmed cases of children's pre-existence memories with paranormal aspects that apparently cannot be explained by childish fantasy. The anomalous phenomena mostly comprise extrasensory perception with one case involving psychokinesis. Such aspects are similar to and convergent with paranormal aspects of neardeath experiences and point to a common, non-physical origin of both types of experiences.
\end{abstract}

KEY WORDS: spiritual pre-existence memories, pre-birth memories, veridical perception, psychokinesis, near-death experiences, apparently non-physical veridical perception

Titus Rivas, MA, MSc, is a theoretical psychologist and philosopher living in Nijmegen, The Netherlands. He is affiliated with Athanasia Foundation and Netwerk Nabijde-doodervaringen and works as an independent author, researcher, and lecturer. His areas of scholarly focus include psychical research, parapsychology, and philosophy of mind. Elizabeth M. Carman, LHD, is a pre-birth awareness educator and former social worker in adoption and foster care. In her latest book, Cosmic Cradle: Spiritual Dimensions of Life before Birth, she and co-author/husband Neil Carman have synthesized 45 years of research, historical accounts, and firsthand natural experiences of the pre-birth realm. Neil J. Carman, $\mathrm{PhD}$, has a life-long love for nature and metaphysics, receiving botany degrees and a $\mathrm{PhD}$ in phytochemistry, and also teaching biology and the science of consciousness. Currently Neil is an environmental policy leader in Texas. Anny Stevens-Dirven was a dedicated, self-made psychical researcher and author who participated in numerous serious projects. She passed away on April 5, 2016. The authors wish to thank everyone who has inspired us to write this article, including all of our fellow prebirth researchers as well as related authors such as Janice Holden, Rudolf H. Smit, Robert Mays, Suzanne Mays, Iris Giesler-Petersen, James Matlock, Kirti Swaroop Rawat, Jim Tucker, Poonam Sharma, Masayuki Ohkado, Michael Maguire, and last but not least, Toni Maguire. Correspondence regarding this article should be sent to Mr. Rivas at email: titusrivas@hotmail.com. 
They often describe a spiritual existence, that is very similar to the existence reported in Near-Death Experiences.

-Michael and Toni Maguire, Spiritual Pre-Existence, www.prebirthmemories.com

The term "spiritual pre-existence memories" in young children is used to refer to what appear to be personal recollections of experiences relating to a state of being in which the person in question would have been a "discarnate" spirit without a physical body during a time prior to birth in the material world in the current biological lifetime (Bauer, Hoffmeister, \& Görg, 2005; Carman \& Carman, 2013; Hallett, 2002; Hinze, 2006; Maguire, 2012; Ohkado \& Ikegawa, 2014; Rawat \& Rivas, 2005; Rivas \& Dirven, 2010; Sharma \& Tucker, 2004; Tucker, 2008). This state may be intermediate or intermissive between two incarnations or simply a state before the present life on earth. Preexistence memories may involve spiritual realms reminiscent of those reported in near-death experiences (NDEs) but also interactions with the physical world.

An example of memories of a spiritual pre-existence comes from a person calling herself Deborah who submitted her story to Michael Maguire's website (www.prebirthmemories.com) which is dedicated primarily to promoting knowledge about spontaneous pre-existence memories and related experiences:

I remember being in a realm, of indescribable beauty and profound peace and joy. It felt like an incredible spaciousness without boundaries ... I was without a physical body, I was light. And surrounding me were many others ... like orbs of the most incredible iridescent light. We communicated via telepathy, and they endowed upon me such an extreme joy and support. There were many of them, and I was connected to all, a sense of belonging and knowing is the best way I can say this.

I was standing at a ledge looking down at the earth, overcome with the most incredible emotions. I could see who my parents would be ... their expectant faces, I did not choose them but rather the opportunity ... "the learning" that would be mine ... I too was filled with such gladness; it is beyond expression, and my words here ... they are like feeble attempts at truly capturing what I felt. I will never forget this. I then remember going through a spiralling tunnel and then a feeling of white static ... I can only equate with the static of a TV that has no channel . . . and then I am aware, in a physical body, laying in the darkness of my crib. My next earliest memory is at 3, and I remember the lighted Mary statue that would play music in the night, I felt comforted by it. (http://www.prebirthmemories.com/Deborah'sStory.htm) 
Memories of a spiritual pre-existence do differ from NDEs in the way they are usually explained. Either pre-existence memories are taken at face value-by a limited number of courageous scholarly pioneers-as a source of information about a spirit world, or, more commonly, they are dismissed as nothing but the product of childish fantasy. Even though a great number of people within mainstream science still regard NDEs as also being illusory, most scholars have by now tended to accept that NDEs are at least subjectively real experiences rather than just fabricated.

A fruitful approach to the question whether NDEs are more than a purely subjective, dreamlike phenomenon is the study of so-called apparently non-physical veridical perceptions (AVPs), in which NDErs' seemingly impossible NDE perceptions-along with other paranormal aspects-are later confirmed as accurate (Greyson, Holden, \& van Lommel, 2012; Holden, 2009; Rivas, Dirven, \& Smit, 2013). NDEs may possess aspects that are anomalous in the sense that they do not fit the so-called 'skeptical,' materialistic worldview. A recent, welldocumented example, published in the Journal of Near-Death Studies, concerns the AVP of a patient of the late physician Lloyd A. Rudy and his assistant Roberto Amado-Cattaneo (Rivas \& Smit, 2013).

This focus on so-called paranormal aspects of NDEs can also be applied to the study of spiritual pre-existence memories. In this short article, we present from the available literature a brief overview of cases of pre-existence memories with paranormal aspects. We have subdivided cases with such aspects into two categories: (a) 7 cases that contain only the statements of the subject oneself, and (b) 22 cases in which the paranormal claims are substantiated by a confirmation from a third party and in which normal explanations seem unlikely.

\section{Cases Without External Confirmation}

\section{Jennifer}

A woman in her thirties named Jennifer shared the following experience on the website prebirthmemories.com:

The day I was born May 31 1976, I watched my own birth. I remember travelling down the hospital hallway, where I entered a room. To my left was my father talking to a nurse, and on the scale was a baby (me). I entered the baby and began to cry. I can still feel the cold scale. I described this event in detail to my parents at the age of three or four and my dad said it was very accurate. It has always made me feel more connected with the universe. (http://www.prebirthmemories.com/The ColdScale.htm) 


\section{Vincent B.}

Vincent, now in his 20s, was a teenager who participated in a serious Dutch documentary series by Michel Kapteijns about children with exceptional views and experiences, entitled Binnenstebuiten (Inside out). This series was broadcast in 2005 for the quality public broadcasting station VPRO. The participating Dutch children of both sexes typically received special education, due to real or apparent disabilities such as a disorder on the autism spectrum. However, from an alternative perspective, largely adopted implicitly in the documentary series, the children could also be seen as highly sensitive (in a nonpsychiatric sense), intellectually gifted, or paranormally gifted, and as deserving of a platform from which to share their perspectives.

After the series was broadcast, co-authors Dirven and Rivas contacted Kapteijns and had several long interviews with Vincent in 2006 and 2007. Among many other things, Vincent told them that he had pre-existence memories.

When Vincent was about four or five years old, memories of a preexistence suddenly came back to him. This experience was quite emotional for him, and he almost had to cry because he felt so moved and overjoyed that he was allowed to recall those memories.

He realized that he already existed before he came to earth, "in heaven or in the afterlife. You are in some kind of universe, it was totally black." These memories were much clearer than any images one sees on television. First, everything was black, but then he saw himself in his mother's womb. He saw only himself.

Just before he was born, he received a kind of preview about the life he would be leading. This preview came at a moment in time before his physical birth at which point he was no longer able to make any choices because he'd already chosen the parents he was going to be born to. He received what seemed like a guided tour and was shown incomplete, fragmentary images of his parents, himself, and the way he was going to be in the life to come. The images were not very rich, but Vincent did not exclude the possibility that he could recall only fragments of them. The images he saw of his parents seemed like photographs of what they would look like when he would be around the very age he remembered his pre-existence. In other words, they seemed to be images of the future, as if they were meant to announce what he should expect. "This is what you get for your money. You've made a choice, these are your parents, this is what they will look like. Good luck!" Subsequently he was born, and the images and memories disappeared 
until he regained a particular level of self-awareness around the age of four or five (Rivas \& Dirven, 2007).

\section{Karim}

Karim was a psychically gifted teenage son of a Dutch mother and an Egyptian father. Like Vincent B., he participated in Michel Kapteijns's TV-series Binnenstebuiten (Inside Out) about exceptional views and experiences of children.

In 2006, through Kapteijns, Rivas and Dirven contacted Karim, still a teenager, and his mother, Veronica, and interviewed them rather extensively. Among the many special experiences Karim described to his mother were also prebirth memories. When Karim was approximately four years old, he told Veronica that he had chosen her as his mother. At the time, he had been able to fly, although he wasn't a bird. He flew into some kind of tree, and that's when he saw his parents and was born to them. The funny thing was that he saw them in a future situation, in a house where they would live after he was born.

Around the same age he added:

Mom, I came to earth on a blue ray. If you go to earth, you simply go there on the blue ray and that's how you are born. And I was born with you because I just knew you would understand me. (Rivas \& Dirven, 2007, p. 32)

\section{Henny van Sleeuwen}

In the summer of 2003, Dirven and Rivas were approached by Mrs. Henny van Sleeuwen, a woman in her 40s, from Rosmalen, The Netherlands. As a child of about seven years, she told her mother about vivid memories of another realm in which she dwelled before being born into this world. She recounted:

I was in a big white room with a white bed. I was lying in the bed and was very ill. I don't know what was wrong with me. I couldn't move any part of my body except for my eyes.

Next to my bed there was a nun watching over me. She wore white clothing and a nun's hood. Like the ones nuns used to wear. Everything was white and bright.

On the other side of my bed there was a door. The door opened and a young woman or girl, about eighteen years old, looked inside and entered the room for a little while. She was about 1,60 [1.6 meters] tall and slim and she had dark blond curly hair, a brown coat with large buttons and a small pair of spectacles. 
The nun lifted up my head, so that I could look better at the woman, and after doing so, I said: "Yes, this is the woman I want to have for my mum."

Suddenly I was waiting somewhere and it took quite a long time before I heard or saw anything. There was some kind of long cylinder in front of me. I was ready to go to a new life, but I had to wait to get permission, probably from God, though I'm not sure. There was an all-embracing, invisible voice that could be felt as some sort of energy. This voice was the "boss." It said: "Are you sure you can deal with it?" "Yes, I can", and I nodded my head confidently.

Once more, the Voice asked me: "Are you completely certain?" Yes, I said, and nodded again. Nothing happened yet. A few moments later, the Voice said: "Are you absolutely sure that you can deal with that?" I probably thought about what they showed me of the life I'm having now, though I can't remember what exactly I was shown. Again, I told him: "Yes, I'm certain, I can handle it." I suppose that I knew what I had to face in this life, though as a child I had already forgotten.

In this life, when I was about seven years I told all this to my mother and she said: "I really had such a coat, camel-coloured with very large buttons and long curly dark blond hair, and a pair of small spectacles, when I was about eighteen." So she recognized everything and I normally couldn't have known any of this. (Rivas \& Dirven, 2010, pp. 15-16)

Henny also told Dirven and Rivas that her life had been very tough, especially because of a father with a disability whose condition had been deteriorating over the years and also because she lost her mother at an early age.

\section{Anne-Marie}

A Dutch woman of unknown age named Anne-Marie recalled that as a child she had had pre-birth memories. She wrote Rivas and Dirven:

I did not want to be born, I was panic-stricken. A friendly old man with a beard softly tried to persuade me that I should go to earth. He promised me I would never be alone. There would always be beings to assist me. My fears were based on the images of the life I was facing. I really didn't have the courage. Finally, I was born anyway, very frightened, while the man was trying to reassure me. Considering my life; everything happened as seen (during the intermission period). The promise has been kept till this very day. (Rivas \& Dirven, 2010, pp. 14-15) 


\section{Kirk D. Gardner}

As a young child, Kirk D. Gardner had strong memories of his greatgrandfather, Apollus. He wrote in the book We Lived in Heaven by prebirth experience researcher Sarah Hinze (2006):

At eighteen months of age, ... I vocalized my thoughts for the first time: Where is the man with the beard? Where did he go?

The adults were stunned. At the time I knew nothing about GreatGrandpa Apollus' earth identity. He had died in 1924, fifteen years before my birth. I knew him only as the radiant presence who helped me to incarnate into human form. ...

Well, I kept pestering everyone for days, repeatedly asking for the 'man with the beard.' I was desperate to see Great-Grandpa again. To appease my requests, I was shown numerous photographs from family albums. Each viewing resulted in the same response: 'No. That isn't him'. . . One day, as a last resort, my mother pulled out a portrait of her long-dead grandfather. He had a beard. Instantly, I recognized the picture of Great-Grandpa Apollus. I was ecstatic. . . . 'Where is he? I want him to come back.' (Hinze, 2006, pp. 69-70)

\section{Lola Brady Everett}

A woman of unknown age, Lola Brady Everett from Fairfax, Virginia, sent Wayne Dyer and Dee Garnes (2015) the following message:

As a small child, I had a clear memory of watching my parents before birth: I was looking down at them from above as they sat in a park. Years later my mom and I were talking, and she mentioned their favorite spot in a park, which they had gone to as a young married couple.

I asked her to take me there, and it was the exact spot from my memories. (Dyer \& Garnes, 2015, p. 24)

\section{Cases With External Confirmation}

With a few exceptions, the following cases were directly collected from the respondents by scholarly authors and researchers. The exceptions concern accounts that were shared on websites but could not be investigated further, because the sources of these cases did not leave sufficient contact details. 


\section{Christina}

Christina K. (pseudonym) was a Dutch girl living in Malden. In 1982, when she was about $3^{1 / 2}$ years old, she told her mother, Hannie K., about a frightening dream in which she suffocated after fire had broken out in her house. In the dream she was an older girl and had other parents. After she died she met a woman dressed in white who showed her several possible future parents. She chose a young lady with blond hair who was working as a typist. The woman or "angel" told her that in that case she would have to wait for some time before she could be reborn.

Rivas first learned about this case in 1997 when Hannie K. was in her 40s and Christina had died in a car accident. He approached relatives and friends of Christina's who confirmed to him that she had repeatedly told them about the dream long before her untimely tragic death.

Rivas and Dirven managed to find a historical fire in Arnhem during 1973 that matched most of Christina's statements. Hannie K. told them that in the period in question she had indeed dyed her hair blond and had a job as a typist. Christina could not have known this information when she told her mother about the dream, as the mother did not dye her hair anymore and worked as a housewife (Rawat \& Rivas, 2007; Rivas, 2000).

\section{Dina}

An anonymous mother shared the following experiences with her daughter on the website prebirthmemories.com:

Back in 1998, after a series of treatments which lasted for about a year, I finally became pregnant with a baby girl. Everything seemed to be OK with the baby but, nevertheless, I lost her when I was sixand-one-half months pregnant. The baby turned out to have a lot of serious problems, with an unknown origin, but the main feature were the deformed hands, with the thumb misplaced.

About three months after the loss, I was so desperate (and, being a spiritualist, my actions can be well understood) that I decided to talk directly with the spirit of my deceased daughter, and asked her to come back, no matter how. One month later, without any treatment at all, I was pregnant again and, this time, the pregnancy went $\mathrm{OK}$ and I had a beautiful baby girl (my only living daughter).

About two weeks ago, when we were preparing to go to bed at night, and my daughter was extremely relaxed, she faced me and said: "Do 
you remember when $\mathrm{C}$ (her name) was a little baby? She didn't want to come, because her hands were not right. But now, the hands are good !! Look !!". I was speechless. There was no way she could have known about the other baby, and definitely about the problem with the hands (only I and my husband know about it).

To complete the story, two days later she told me, also in a casual manner, that my grand-father (who's been dead for twenty-two years now) is going to be born again, because he's tired of waiting. (http:// www.prebirthmemories.com/Dina's Story.htm)

\section{Four-Year-Old Western Girl}

An anonymous mother shared the following experience on the website prebirthmemories.com:

When my daughter was about four years old, she told me that she had met her big sister. When I corrected her and reminded her that she only had a big brother, not a big sister, she corrected me and told me that she met her big sister in heaven, because her sister did not come to earth. She did not know what a miscarriage was, nor did she know that I had one before her brother was born.

When she was seven years old, I found her looking off into space with a sad expression on her face. I asked her what was wrong and she told me that she was starting to forget. I asked what she meant, and she told me that she was starting to forget what it was like in heaven and how the angels sound.

As a footnote, my daughter was born eight weeks premature. I have met other parents of preemies [premature infants] who have shared stories of pre-birth memories from their children. I am wondering if this is a common occurrence. (http://www.prebirthmemories.com/ Meeting Her Big Sister.htm)

\section{Veer Singh}

An Indian boy named Veer Singh was born in 1948. From the age of about 3 years, he recalled a past life as Som Dutt, who died in 1937. He also had memories of an intermission period. Reincarnation researcher Ian Stevenson (1975) wrote about these memories:

He said that he had accompanied any member of the family [of the previous incarnation] who went away from home alone. This statement accorded with a dream Som Dutt's mother had had some months after his death . . . in which Som Dutt appeared to her and said that his older brother, Vishnu Dutt, was going out at night to attend fairs and that he ... was accompanying him. . . Bindra Devi [Som Dutt's 
mother] did not know that Vishnu Dutt was leaving the house to attend the fairs but after her dream, upon enquiring, found this was true. Vishnu Dutt confirmed this to me. . . . . Veer Singh also told Laxmi Chand [Som Dutt's father] the names of the children born after Som Dutt's death. ... Veer was credited with recognizing these other children....

He described how some women were playing on a swing suspended from the peepal tree he claimed to have occupied. He felt irritated by their intrusion and thought of breaking off the branch of the tree supporting the swing. Then he reflected that he might kill them. So instead he waited until the swing was near the ground and then broke the plank on which they were sitting. Laxmi Chand remembered that an accident of this type had happened after the death of Som Dutt. (Stevenson, 1975, pp. 328-329)

Stevenson (1997) related this confirmed instance of an apparent psychokinetic effect during a discarnate existence to unconfirmed cases in Myanmar:

Persons in Burma claiming to remember experiences in a discarnate realm during the interval between a previous life and their birth sometimes say that they threw stones at living persons in order to harass them or sometimes "just for fun." . . . And living persons in Burma have sometimes claimed that stones had landed on or near them during the period when the subjects who later remember these pranks say they had engaged in them. (Stevenson, 1997, p. 183)

\section{James Leininger}

American boy James Leininger, now 17 years old, is known for his verified claimed spontaneous memories of a previous life as a World War II fighter pilot as expressed from the age of 2 years. The case has been documented and studied by renowned reincarnation researchers Jim Tucker (2008) and Carol Bowman (2012).

Also among James's memories were those of an intermission period between his former incarnation and his present life. One day, he and his father, Bruce Leininger, a human relations professional in the oil industry, were outside their home. James told his father, who at the time did not believe in pre-existence, that he (James) had picked his father because he knew his father would be a "good daddy." When Bruce requested clarification, James said that he found his mother Andrea and him in Hawaii at the "big pink hotel." In fact, Bruce and Andrea had celebrated their fifth wedding anniversary in 1997 at the Royal Hawaiian Hotel, which was painted pink. That was five 
weeks before Andrea got pregnant with James (Leininger, Leininger, \& Gross, 2009).

\section{Younger Brother}

A woman of unknown age who was simply called "Mrs. L." told one of the authors of the book Children Who Communicate Before They Are Born that she had a younger brother who couldn't develop a real trusting relationship with his mother. When he was 3 years old he suffered from high fever, and during a "fever dream," that is, during an altered state caused by his fever, he disclosed that his mother had "repeatedly pushed him back into the water" (Bauer, Hoffmeister, \& Görg, 2005 , p. 78). Before he was born, his mother had had several abortions (Bauer et al., 2005).

\section{Sue's Daughter}

A Canadian therapist shared this story with author Elisabeth Hallett (2002):

At the age of seventeen, Sue had an abortion without consulting her parents. Afterwards she felt very remorseful and came in for therapy in which we worked on the grief for what she had done. A year later when finding herself pregnant again, she came in to see me and I took her into hypnosis where she could talk to her baby. She saw a pink bundle and held the baby and talked to her. The baby said she wanted to be born, and Sue felt a strong connection with her this time. She went on to have the baby girl and kept her with help of the parents.

When the little girl was about three, Sue had to go into the hospital with an allergic reaction to something she had ingested. The grandmother took the child in to visit her, but when the little girl saw her mother in the hospital bed, she started screaming and had to be taken out of the building. When asked why she was so upset, the child replied, "I drowned in that hospital." (Hallett, 2002, p. 149)

\section{Bobby Hodges}

Tucker (2008) described the case of Bobby Hodges, a boy from North Carolina, who frequently talked about wanting to live with his cousins:

His cousin's family consisted of one boy, the oldest child, and three girls. In addition, Bobby's aunt had miscarried a set of twins after her son was born. Bobby said that the boy was his big brother and asked why his mother was keeping him from his real family. He repeatedly 
said that he belonged with his cousins. His parents . . never gave his statements much thought until he began talking to his mother one night after his bath when he was four and a half years old.

He asked her if she remembered when he was in her tummy. He then asked if she remembered when he and Donald were in her tummy. She said yes and asked if he remembered when his two-anda-half-year-old brother Donald was in her tummy. He then asked if she remembered when he and Donald were in her tummy at the same time. When she told him that they had not been in her tummy at the same time, he said they were in her tummy at the same time but did not get born. She told him that he did get born and later Donald was born. He responded that he and Donald had been in his Aunt Susan's tummy at the same time, rather than his mother's, and asked why Aunt Susan did not give birth to them.

Then, Bobby became very upset and began screaming at Donald. He said, "Donald, it is all your fault. I told you I wanted to get born real bad, and you didn't want to. How did you take me out of there, Donald? Why didn't you want to get born? Tell me how you did it. Tell me how you took me out of there. ..."

Donald then took his pacifier out of his mouth and yelled, "No! I wanted Daddy!" before popping his pacifier back in. Bobby shouted, "I didn't want Daddy, I wanted Uncle Ron."

Seven years before Bobby was born, his Aunt Susan was pregnant with twins; they stopped moving at thirty-three weeks because one of them had rolled over on the umbilical cord.

After the miscarriage he unsuccessfully tried to enter another body before finally reincarnating as Bobby Hodges. (Tucker, 2008, pp. 164-167)

It is possible that the veridical elements in this case exclusively relate to an incarnated prenatal phase rather than to a discarnate existence. However his unverified claim of trying to enter another body before his present one seems to suggest a continuity between his prenatal and discarnate memories.

\section{Elizabeth}

An American woman called Lezlie had a miscarriage in the early 1980s. A new pregnancy culminated in the birth of healthy baby girl, Elizabeth, in January 1984. Lezlie's daughter began to walk and talk at an early age. Lezlie recounted:

Since Elizabeth was teeny-weeny, she told me unprompted, 'Oh, yeah, Mom, I was in your tummy twice. The first time I washed away. The second time, I came out like a zipper.' I had never mentioned the miscarriage to her. ... 
Later, when Elizabeth was seven, the subject came up about losing the first baby. We were driving through Coronado, a part of the city Elizabeth had not been to before. As we passed the Coronado Bridge, Elizabeth pointed out an inconspicuous building and said, 'I was in that building.' I replied, 'That was the building where my doctor's office was when I was pregnant with you the first time.'

Elizabeth said, 'I remember the miscarriage, Mom. That was me. I was a boy, and you and dad had a fight. I chose to leave and come back as girl....

Lezlie: "I had sensed that we were going to have a boy.... So one night my husband was adamant about circumcision. He said, 'If we don't circumcise, he'll be regarded as odd by the boys in the locker room.' I felt just the opposite: 'I will not put my baby through that torture. Under no conditions will I allow our child to be circumcised.' Neither of us was willing to budge. My husband was upset and did not grasp how important it is not to create birth trauma. That argument happened when I was twelve weeks pregnant. I had the miscarriage the next morning. At that time, I didn't link the argument to the loss." (Carman \& Carman, 2013, pp. 47-50)

\section{A Friend's Daughter}

Physician Gladys McGarey (2000) reported this case. A 17-year-old girl named Susan explained to her unborn child why the time was not right for her to become a mother. "You will only be away a little while. We will be together again." Susan spontaneously miscarried in the third month of pregnancy. Two years later, a child's voice awoke Susan one night: "Mama, I'm coming back." Susan knew it was her little girl returned. This was the same night her friend birthed a baby girl. A strong love bond unfolded between Susan and her friend's daughter. One day the 3-year-old child asked Susan, "Do you remember when I was in your tummy?" "No, honey, you were in your mother's tummy," Susan said. The girl shook her head. "Not that first time." Susan asked, "What did you do in my tummy?" The little girl replied, "I cried. The ones that brought me to you said I couldn't stay; it wasn't the time." The three-year-old touched her navel as she explained: "They pulled me back with a long silver cord" (McGarey, 2000, pp. 69-72).

\section{Desmond}

Reincarnation researcher Carol Bowman (2012) reported this case:

Desmond [age unknown] told his mother that he went to Aunty Ruth before he came to her, but he didn't stay there very long. Desmond 
recalled his time in Aunty Ruth's womb as happy, comfortable, wet, warm, dark, but not scary. It felt bouncy, and he turned around and around all the time. One time Desmond fell sleep, and when we woke up, he was no longer with Aunty Ruth. Without knowing it, he was referring to Ruth's birth of a stillborn son ten years before Desmond's birth. The family never spoke about his traumatic event. (Bowman, 2012, p. 147)

\title{
Johnny
}

Lois P. told Hinze (2006):

I was putting three-year-old Johnny to bed when he asked for a bedtime story. For the past few weeks, I had been telling him of the adventures of his great-great-grandfather: a colonizer, a soldier, a community leader. As I started another story, Johnny stopped me and said, 'No, tell me of Grandpa Robert.' I was surprised. This was my grandpa. I had not told stories of him, and I could not imagine where he had heard his name. He had died before I had even married.

'How do you know about Grandpa Robert' I asked. 'Well, Momma,' he said with reverence, 'he's the one who brought me to earth.' (Hinze, 2006, p. 27)

\begin{abstract}
Alan
This case was described by Betty Clark Ruff in an account titled Taught by a Toddler that Ruff wrote for Hinze (2006).

After his great-aunt Lida had passed away, Betty Clark Ruff's son Alan, just past two, said with a happy smile:

"Oh, I know what it's like. Grandpa Clark brought me when I came to you. He'll probably take me back when I die."

His mother reports: "Alan then proceeded to describe his grandfather Clark, my father, who had been dead nearly twelve years. Alan had never even seen a picture of him. But he told how much he loved his grandfather and how good his grandfather had been to him. Alan indicated that my father had helped to teach him and prepare him to come to earth.

Immediately after this occasion, Alan's father talked to him and Alan repeated the same experience to him. Alan later told his grandmother Clark about the experience. (Hinze, 2006, pp. 28-29)
\end{abstract}

\section{Maung Zaw Thein Lwin}

A boy in Upper Burma (Myanmar), Maung Zaw Thein Lwin, from the age of around 3 years, recalled a previous life as U Mar Din and an 
intermission period between that life and his present existence. About the latter he said that he had to live in the precincts of the pagoda at Pan Aing. He also described how he had become as small as a speck of dust and in this form had got into his mother's drinking water-but she had noticed the speck and thrown out the water. He then made himself even less visible and so had got into her when she drank the next water in which he had placed himself.

Maung Zaw Thein Lwin said that during his discarnate phase he had appeared to Daw Khin Shein (the wife of the previous life) in a dream and told her where he had left 5 kyats (Burmese money) wrapped up in a white handkerchief. Maung Zaw Thein Lwin wished to know whether Daw Khin Shein had had such a dream.

Daw Khin Shein told U Win Maung, a local researcher, and Ian Stevenson:

that she had indeed had such a dream and that it included the detail that the white handkerchief, in which the 5-kyat note was wrapped, was itself in a small box of basket work. These clues had enabled her to find the handkerchief and the 5-kyat note. The money itself was not important to her; but the verification of the instructions given ostensibly by the discarnate U Mar Din was. (Stevenson, 1997, p. 255)

\section{J.}

Mrs. E shared the following prebirth memory of her son J., aged $31 \frac{1}{2}$ years. He told her:

Above the sky, there is another sky, and that is where I was. I wanted to come earlier, but that was not possible, because an airplane was in the way, but then I did this (he boxes with his fists) and then I came.

At the time, his mother had been single, and she had been working as a travel agent for an airline in Greece. (Bauer et al., 2005, p. 68)

\section{Five-Year-Old Japanese Girl}

A Japanese 5-year-old girl said to her mother: "I saw you in a gorgeous white dress. You were holding a dog" (Ohkado \& Ikegawa, 2014, p. 483). The mother had indeed held a dog while wearing her wedding dress. After the wedding ceremony, she had entered a room where the dog was awaiting her return. The mother clearly remembered this episode because holding a dog in a wedding dress is not something a bride is supposed to do (Ohkado \& Ikegawa, 2014). 


\section{Six-Year-Old Japanese Girl}

A girl in Japan who was 6 years old at the time drew a picture of a four-story building surrounded by mountains and said, "This is where you lived. I saw you there" (Ohkado \& Ikegawa, 2014, p. 483). Her mother was astounded because, as a child, she lived in a four-story building from which she could see the surrounding mountains (Ohkado \& Ikegawa, 2014).

\section{V.}

Now in her 20s, philosopher V. reported that as a young girl she told her Dutch parents about her memories of a spiritual pre-existence. Her mother Anke confirmed this report to Rivas and Dirven. However, V. had only recently shared a veridical perception with Anke of a specific event that she had witnessed approximately 30 years before, when a spirit guide tried to convince V. to incarnate.

In fact, before V.'s birth, Anke was standing on a specific spot outside her house when she had a memorable spiritual experience of unity. This experience happened after the other children had gone to school. Anke stated that V. had described this rather private experience very accurately, including the situation and physical characteristics of the location where it happened (Rivas \& Dirven, 2009).

\section{Jean Chapman's Son}

Gladys McGarey (2000) published the following experience that her colleague, Dr. Jean Chapman, reported to her:

My son was three and a half. We were talking about what fantastic times we had playing together. We had just been in a skiing area and we were driving home. I said offhandedly, giving him a little pat, 'I sure wish you had come into my life sooner. Think of all the fun we've missed. . . . he announced, 'Well, I tried twice before, but you weren't ready, so I had to go back. . . . I had to wait.' (McGarey, 2000, p. 58)

Chapman marveled because she realized that no one was aware of the fact that she had had two miscarriages (McGarey, 2000).

\section{Dottie}

In another account from McGarey (2000), 4-year-old Dottie told her mother Phyllis that she once had had another mother and that be- 
tween that life and her present one, she had already been in Phyllis's tummy before: "The last time, Mommy, was when I was four inches long and I was in your tummy. But Daddy wasn't ready to be my daddy yet. He wasn't ready to marry you. And so I went away" (McGarey, 2000, p. 60).

McGarey explained that there had been an abortion at a time the fetus would have been that size. Except for the father, no one had known about this abortion. They had been in a romantic relationship; while the father was still married to another woman. Phyllis married him two years later when his divorced was eventually finalized. (McGarey, 2000)

\section{James from the UK}

An 11-year-old English boy named James told his mother Louise McGrath from Manchester how he had a meeting with God before coming to Earth and how his soul traveled in some kind of vehicle. He also said that he remembered being in her tummy and even saw the playroom that his parents were converting before he was born.

"He couldn't really have seen this once he was born, as we moved soon after I gave birth and we'd never mentioned it!" (Dyer \& Garnes, 2015, pp. 120-121)

\section{Michael}

On May 26, 2014, a woman who called herself Nicola E. Friend shared the following story at the Near-Death Experience Research Foundation website (www.nderf.org):

My friend and I met as school teachers at the same school, several years ago. She was pregnant when we met, and she chose me to be present at the birth of her child, because she was a single mother and afraid of being alone. [ . . ] ]

My friend delivered a baby boy named Michael, and it was an incredible experience. I joked to her that I saw her son before she did! (I saw his head poking out before he was born and she didn't have a mirror to see for herself!)

Tragically, my friend passed away suddenly, just months after her son was born. He has been raised by her parents ever since. The boy now goes to the school where his mother and I taught, and this year he is in my 4th grade class. It is with a heavy heart that I teach him each day. I have never told him that I was there for his birth because I didn't want the other students to think that he had special treatment, 
and I didn't want to upset him with thoughts of his mother. Perhaps his grandparents told him that I was there, but I'm not sure. He does know, however, that his mom and I were friends. (This makes sense because he knows that she used to teach at our school.)

Flash forward to last week, 9 and a half years after his birth and his mother's passing.

I was speaking with my class about our memories, for a poetry writing assignment. I asked them to think back to the earliest memories they have. Most students talked about Kindergarten, or perhaps day care, or vague memories of old toys, etc from when they were about 3-4 years old.

Michael put up his hand and said that he remembers watching everyone from up in the sky, and being in his mother's belly before he was born. He said that when he was waiting to be born, he was invisible and he was in my GREY car with me on the way to the hospital while I listened to the song "Winter Spring Summer or Fall." (This is what he called the song. He likely doesn't know the real name, and he probably hasn't heard it since . . . but it was "You've Got a Friend" by James Taylor. I used to have the cassette tape in that car!!! This is bizarre because I did drive a grey car at that time and I haven't had one for the past 7 years (2 years after he was born). I can't imagine he even knows that song from today's radio music. My heart started to beat like crazy. How the heck would he know that? Even his grandparents wouldn't know that and his mom wouldn't have known that before she died. Even if somehow she did, he was only three months old when she passed. How would she tell him? I certainly never told her what song was on in my car on the way to the hospital so I can't explain this!

Michael said that he remembers me stopping for gas and asking the attendant for directions to the hospital (TRUE). He said that he wanted me for his mommy because he liked my voice when I was speaking to the attendant. (I did stop for gas and I was kind of lost going to a rural hospital, so I asked for directions). Then he said that he remembers that the parking lot was partially closed for construction, so I had to park on a corner and run to the hospital. By this point my jaw was almost on the floor and the whole class was staring at me. I had never even told the class (or Michael) that I was at his birth. The class must have thought this was one crazy story.

Then Michael said the most incredible thing-He said that while his "real mom" was in labor, he asked God if I could be his mom because he knew that his "real mom" wouldn't survive very long, and he was afraid of being alone on Earth. Apparently he was told that he couldn't have me for his "real mom" but that everything would be OK and he would still get to be around me during his life.

Michael said that he kept begging for me to be his mother. He watched me go down the hallway from the birthing suite to the waiting lounge to make a phone call from a pay phone (true-there was no 
cell signal in the hospital), and that while I was there I was very cold so I put on a sweater that someone else left on the waiting room chairs. By this point the hairs on the back of my neck were standing up. I hate to admit this, but I did find a nice warm cardigan in that waiting room and I put it on because I was so cold. I've never done anything like that before, but it was a small hospital and there were literally no other people in the labor ward and I waited to see if anyone would come to claim the sweater, and no one did. I was so cold! I put it on and ended up wearing it home. (Shame on me, I know, I still feel guilty about that.) I've felt so guilty that I never wore it again, especially because it reminds me of my friend who ended up passing away. Regardless, I have to mention it because I've never told anyone about taking someone else's sweater, and it's a huge part of this story!!!!

Michael concluded by saying that he watched me make the phone call and put on the other person's sweater, and that's the last thing he remembers. He was born about thirty minutes after I went to the lounge and made that phone call.

Later, I privately said to Michael, "Yes, I was at your birth. How did you know all of that stuff?" His grandparents weren't at the birth and there was literally no way he would have known any of that. How could he make it up? He said that it's easy, he just had to think back to his earliest memories. He asked me why I don't remember being born, too and he said, "It's OK, my life did turn out OK. So don't worry about not being my mom." (http://www.nderf.org/NDERF/ NDE_Experiences//'nicola_e_friend_other.htm)

\section{Discussion}

We have presented 29 cases of pre-existence memories with paranormal aspects, 22 of which involve external confirmation. Although the number is smaller than that of cases of NDEs with confirmed paranormal aspects, this difference may be explained through the limited attention that conscious memories of a spiritual pre-existence have so far received from serious scholars and, of course, by the possibility, if not likelihood, that such memories themselves are less common than memories of NDEs. The paranormal phenomena reported include clairvoyance of events in the physical world, telepathy, and psychokinesis (in the case of Veer Singh). These phenomena are also reported in NDEs, although psychokinetic effects are just as rare in verified NDEs.

Just like NDEs that occur during cardiac arrest while there is insufficient cortical blood flow to account for the presence of usually lucid and complex consciousness, these pre-existence memories appear not to be plausibly explained by the workings of the brain. There is no 
good, specific reason to suppose that children derive their paranormal knowledge from retrocognition-extrasensory perception of the past-rather than real-time clairvoyance and telepathy. In this context, retrocognition is no more than an ad hoc hypothesis to uphold the dogma that consciousness and memory always need a functioning brain.

Michael Sudduth (2016) has claimed that an explanation based on a brainless consciousness would require auxiliary hypotheses that reduce its plausibility in comparison to retrocognition and other types of "living agent-psi." An example of such an auxiliary hypothesis is that there is an irreducible, personal psyche or Self, with a non-physical mind (including cognition and memory) that interacts with the brain during biological life, and uses extrasensory perception in a discarnate state. However, such so-called auxiliary hypotheses do not clash with known psychological mechanisms. The pre-existence of an irreducible Self with an active, working mind and ESP powers is fully compatible with any data collected by mainstream psychology (and neuropsychology), even if those data contradict dominant theorizing. In contrast, a living-agent account of veridical pre-existence memories would imply that even children of parents who did not originally believe in preexistence, such as the Leiningers, would unconsciously use retrocognition (retrocognitive telepathy or clairvoyance) in order to collect information about a period before their physical conception and build a bizarre fantasy around this paranormal information. In principle, such processes might be plausible in cases of children who belong to cultures or subcultures in which people believe in pre-existence; the memories "confirm" their cultural assumptions. However, what could be the hidden drive for young Western (non-Mormon) children to produce such fantasies if the concept of a spiritual pre-existence is alien to their cultural and religious background and does not match typical developmental phases in children's formation of concepts about life, birth, or death?

On a related note, some evidence indicates that young children and even babies are "natural-born dualists" (Bloom, 2004). This evidence does not imply that the notion of a spiritual pre-existence is an intrinsic part of their supposedly innate dualist worldview. Instead, young children typically seem to have at best a vague or confused concept of what it means to be physically alive or dead. It is only after the boundaries between physical life and death have become clearer for these children, around approximately 5 years of age (Speece \& Brent, 1992), that they might be expected to construct fantasies about pre-existence 
consistent with their supposed natural dualism. This argument is also relevant for reincarnation memories in young children.

The auxiliary hypothesis needed to make the retrocognitive hypothesis plausible would be that these children were subconsciously motivated to fantasize about a spiritual pre-existence for no understandable motive and that in the process their fantasies would, coincidentally, end up being very similar. A process such as this would contradict established principles of psychological dynamics. This argument implies that, contrary to Sudduth's (2016) conviction, the living-agent interpretation for these cases is not "just as implausible" as the pre-existence hypothesis, but much more implausible, to the extent that it would lack all plausibility.

Similarly, it might be hypothesized that the adults who reported or corroborated their children's accounts of pre-existence memories enhanced those accounts and/or dismissed inconsistencies in or contradictory information to those accounts. But again, a motive is lacking for adults to do so when such accounts contradicted their cultural and personal worldviews; conversely, one would expect such "skeptics" to look for evidence that invalidated the accounts, but instead adults report them and often are persuaded by them to change their own preexisting cosmological worldviews. Although we are aware of cases in which the account could not be either confirmed or disconfirmed by available evidence, we are unaware of cases in which adults reported children's pre-existence accounts that were explicitly disconfirmedeven though they would presumably be motivated to do so because the discounting would support the adults' existing worldviews.

Beyond the plausibility of pre-existence memories themselves, these memories and NDEs are clearly related and convergent, and they collectively point to the reality of conscious discarnate existence ${ }^{1}$ (Rivas, 2010). This conclusion is supported by a striking similarity between many non-paranormal, spiritual elements of pre-existence memories and spiritual aspects of NDEs, such as the existence of a "heavenly" realm of light and love, the decision to return to earth, and communication with other discarnate spirit beings. It is strengthened further by three specific types of cases: (a) cases in which someone recovers

1. We are aware of impersonalist Buddhist interpretations of pre-existence or "Bardo" memories that depend on the so-called anatta-theory. Although we respect such interpretations, we believe the presence of consciousness presupposes the presence of a conscious experient or Self (Rivas, 2005; Rivas, 2010). 
pre-existence memories during an NDE, such as the case of Betty Eadie who spoke about a "pre-mortal world":

I was actually relieved to find that the Earth is not our natural home, that we did not originate here. I was gratified to see that the Earth is only a temporary place for our schooling and that sin is not our true nature. Spiritually, we are at various degrees of light-which is knowledge-and because of our divine, spiritual nature we are filled with the desire to do good. (Eadie, 1994, p. 49)

(b) cases in which the subject had both spontaneous pre-existence memories and an NDE and claimed that both experiences clearly relate to the same realm, such as the Dutch case of Myriam R. (Rivas \& Dirven, 2010), and (c) cases in which the pre-existence memories contain memories of dying that are indistinguishable from a typical NDE, such as the case of Celal Kaplan. This young Turkish boy described events immediately prior to his death in the previous life, such as the transport of his body in an ambulance and a doctor pronouncing him dead. He also mentioned the washing of his dead body and its funeral (Rawat \& Rivas, 2005).

\section{Implications and Future Research}

Accepting that at least some apparent memories of a spiritual preexistence are real memories would have important implications. For NDE research, such memories would offer additional data on the discarnate state of being that many NDErs describe. For reincarnation research, pre-existence memories reveal what happens to a Self after it has left its physical body and before it enters a new body. For prenatal research, pre-existence memories point to the extent to which an unborn baby is capable of picking up information without neurological and sensory support.

More generally, real pre-existence memories point to the reality of an irreducible Self that is not created by the brain or body and that even precedes bodily life. They demonstrate the importance and value of personal existence-within a world that appears to be much more meaningful than many contemporary scholars have believed.

We believe that pre-existence memories must be heavily underreported. Thus, it is very important for scholars to continue to collect, document, and analyze veridical cases. We believe that spontaneous cases of this type are generally more valuable than (semi-)experimental data produced by hypnosis and other regression techniques (Newton, 1994, 2009; Tomlinson, 2007; Wambach, 1984), because- 
especially in adults - the component of suggestions could lead to false memories. With this caveat in mind, it may still be useful to compare such experimental data with spontaneous memories. Also, unsought pre-existence memories in adults, which unexpectedly occur during a regression, and memories in children and other "naïve" regression subjects may sometimes yield interesting information as well. Furthermore, we consider it very important to carefully analyze similarities between the contents of pre-existence memories and NDEs (Rawat \& Rivas, 2005; Sharma \& Tucker, 2004). Further studies such as these will advance understanding of the nature of and relationship between mind and brain as well as understanding of consciousness in general and meaning and purpose in life.

\section{References}

Bauer, D., Hoffmeister, M., \& Görg, H. (2005). Children who communicate before they are born: Conversations with unborn souls. East Sussex, England, UK: Temple Lodge.

Bowman, C. (2012). Children's past lives: How past life memories affect your child. New York, NY: Bantam Books.

Bloom, P. (2004). Descartes' baby: How the science of child development explains what makes us human. New York, NY: Basic Books.

Carman, E. M., \& Carman, N. J. (2013). Cosmic cradle: Spiritual dimensions of life before birth. Berkeley, CA: North Atlantic Books.

Dyer, W. W., \& Garnes, D. (2015). Memories of heaven: Children's astounding recollections of the time before they came to earth. Carlsbad, CA: Hay House.

Eadie, B. (1994). Embraced by the light. New York, NY: Bantam Books.

Greyson, B., Holden, J. M., \& van Lommel, P. (2012). 'There is nothing paranormal about near-death experiences' revisited: Comment on Mobbs and Watt. Trends in Cognitive Sciences, 16, 445.

Hallett, E. (2002). Stories of the unborn soul: The mystery and delight of prebirth communication. Lincoln, NE: Writers Club Press.

Hinze, S. (2006). We lived in heaven: Spiritual accounts of souls coming to earth. Rexburg, ID: Spring Creek.

Holden, J. M. (2009). Veridical perception in near-death experiences. In J. M. Holden, B. Greyson, \& D. James (Eds.), The handbook of near-death experiences: Thirty years of investigation (pp. 185-211). Santa Barbara, CA: Praeger/ ABC-CLIO.

Leininger, B., Leininger, A., \& Gross, K. (2009). Soul survivor: The reincarnation of a World War II fighter pilot. New York, NY: Grand Central.

Maguire, T. (2012). Memories of the light: A story of spiritual existence before physical birth. Lincoln, NE: iUniverse.

McGarey, G. T. (2000). The physician within you. Scottsdale, AZ: Inkwell.

Newton, M. (1994). Journey of souls: Case studies of life between lives. St. Paul, MN: Llewellyn. 
Newton, M. (2009). Memories of the afterlife: Life between lives stories of personal transformation. St. Paul, MN: Llewellyn.

Ohkado, M., \& Ikegawa, A. (2014). Children with life-between-life memories. Journal of Scientific Exploration, 28(3), 477-490.

Rawat, K. S., \& Rivas, T. (2005). The life beyond: Through the eyes of children who claim to remember previous lives. Journal of Religion and Psychical Research, 28(3), 126-136.

Rivas, T. (2000). Parapsychologisch onderzoek naar reïncarnatie en leven na de dood [Parapsychological research into reincarnation and life after death]. Deventer, The Netherlands: Ankh-Hermes.

Rivas, T. (2005). Rebirth and personal identity: Is reincarnation an intrinsically impersonal concept? Journal of Religion and Psychical Research, 28(4), $226-233$.

Rivas, T. (2010). Is it rational to extrapolate from the presence of consciousness during a flat EEG to survival of consciousness after death? [Letter to the Editor]. Journal of Near-Death Studies, 29(2), 355-361.

Rivas, T., \& Dirven, A. (2007). Vincent, Karim en Danny van Binnenstebuiten: Een drieluik over paranormaal begaafde jongens in Nederland [Inside out: A trilogy about paranormally gifted boys in the Netherlands]. Nijmegen, The Netherlands: Lulu.com.

Rivas, T., \& Dirven. A. (2009). Herinneringen aan de eigen geboorte en wat daaraan voorafging [Memories of one's own birth and what preceded it]. Terugkeer, 20(1), 19-21.

Rivas, T., \& Dirven, A. (2010). Van en naar het Licht: Spirituele preëxistentie, sterfbedvisioenen, bijna-doodervaringen en uittredingen [From and to the light: Spiritual pre-existence, deathbed visions, near-death experiences and out-of-body experiences]. Leeuwarden, The Netherlands: Elikser.

Rivas, T., Dirven, A., \& Smit, R. (2013). Wat een stervend brein niet kan [What a dying brain can't do]. Leeuwarden, The Netherlands: Elikser.

Rivas, T., \& Smit, R. H. (2013). A near-death experience with veridical perception described by a famous heart surgeon and confirmed by his assistant surgeon. Journal of Near-Death Studies, 21(2), 179-186.

Sharma, P., \& Tucker, J. B. (2004). Cases of the reincarnation type with memories from the intermission between lives. Journal of Near-Death Studies, 23(2), 101-118.

Speece, M. W., \& Brent, S. B. (1992). The acquisition of a mature understanding of three components of the concept of death. Death Studies, 16, 211-229.

Stevenson, I. (1975). Cases of the reincarnation type: Vol. I. Ten cases in India. Charlottesville, VA: University of Virginia Press.

Stevenson, I. (1997). Reincarnation and biology (Vol 1). Westport, CT/London, England, UK: Praeger.

Sudduth, M. (2016). A philosophical critique of empirical arguments for postmortem survival. Melbourne, Australia: Palgrave Macmillan.

Tomlinson, A. (2007). Exploring the eternal soul. Hants, England, UK: O-Books. Tucker, J. B. (2008). Life before life: Children's memories of previous lives. New York, NY: St. Martin's Griffin.

Wambach, H. (1984). Life before life. New York, NY: Bantam. 